\title{
Digital Logistics as Institution for Improving Coordination of Flow Processes in Transport and Logistics System of the Smart City
}

\author{
Gleb Savin *, Victor Katochkov, Valeria Grishina
}

\author{
Ural State University of Economics, Yekaterinburg, Russia \\ ${ }^{*}$ Corresponding author.Email: glebsavin@ya.ru
}

\begin{abstract}
In today's world, in the context of digitalization, resources are diverted from traditional economic mechanisms, while information and communication technologies give impetus to new development institutions, which ensure transition to a new technological mode of economic development in the situation of decentralizing economic resources and contributing to a new quality of human life. The proposed institute of digital logistics provides interactions in the development of the transport and logistics system (TLS) of the smart city and is transformed through the formation of world-class infrastructure, providing the needs of its own software, equipment and personnel, replacing human functions with automated algorithms under the new system of economic management. In turn, its development today is an important and dominant factor that allows the control of transactions and transaction costs, as well as the enforcement of rules and regulations for a higher level of consistency in the interaction of economic agents in digitalized economy.
\end{abstract}

Keywords: digital logistics, flow processes, adaptive coordination, TLS mutation, mechanisms of achieving criteria of transformation and development of urban transport and communication corridors, ecosystem

\section{INTRODUCTION}

Today there is a tendency to move away from centralized management, and there is a transition from the C3 paradigm (management, calculation and communication) to the C5 paradigm (management, calculation, communication, lifecycle cost), which reduces transaction costs. Under these conditions, there is a need to control decentralized management systems through formation of new institutional environment. At present a more flexible approach that ensures the coordinated interaction of economic agents and reduces the systemic friction of the system itself, is in demand.

Development of a new management model of coordination of flow processes requires a deeper study of institutional changes, as well as the formation of new norms and rules of interaction of economic agents, which in modern realities is realized in the formation of a common information space in the development of appropriate infrastructure of the smart city TLS.

\section{MATERIALS AND METHODS}

Let us accept [1] that minimization of resource and material costs is insignificant for the transport and logistics system of a smart city, and those systems in which the level of transaction costs is minimal, dominate. Achievement of this indicator is possible only at coordinated functioning [2-4] and development of all economic agents. Thus, economy will act as a category of achievement of adaptive coordination as transition to new modern institutes of development [5].

We emphasize that search for information, costs of preparation and execution of the transaction, protection of specification and property rights, as well as opportunistic behavior with limited rationality act as criteria for evaluating transaction costs; they strive for a minimum value in the ideal flow model of the smart city TLS. The reason for this is that information asymmetry is insignificant due to full access to information in supply chains with open architecture and the value of opportunistic behavior is also minimized by existing restrictions - infrastructure, information space and rules of interaction between economic agents. 
The difficulty in the development of TLS smart city in this situation is the quantitative indicator of economic agents and their intensive growth. Anyway, with the involvement of consumers in the management of flow processes, as well as the use of technology Web 2.0 and above, this indicator is reduced and leveled in the future. Today, current rules of interaction are expressed by institutional environment of the TLS smart city in the field of regulation, organization and provision [6-9], but do not allow to form a transport and logistics system of a new type [10], due to the lack of a systematic approach and the use of digital logistics tools $[5,11,12]$, which in combination contribute to adaptive coordination of flow processes. At the same time, transaction costs, as a basic category of institutional economics, are growing due to systemic frictions in the organization of the city flow processes.

\section{RESULTS AND DISCUSSION}

Development of interactions between economic agents in the TLS of the smart city should be carried out in the field of transportation process, related management

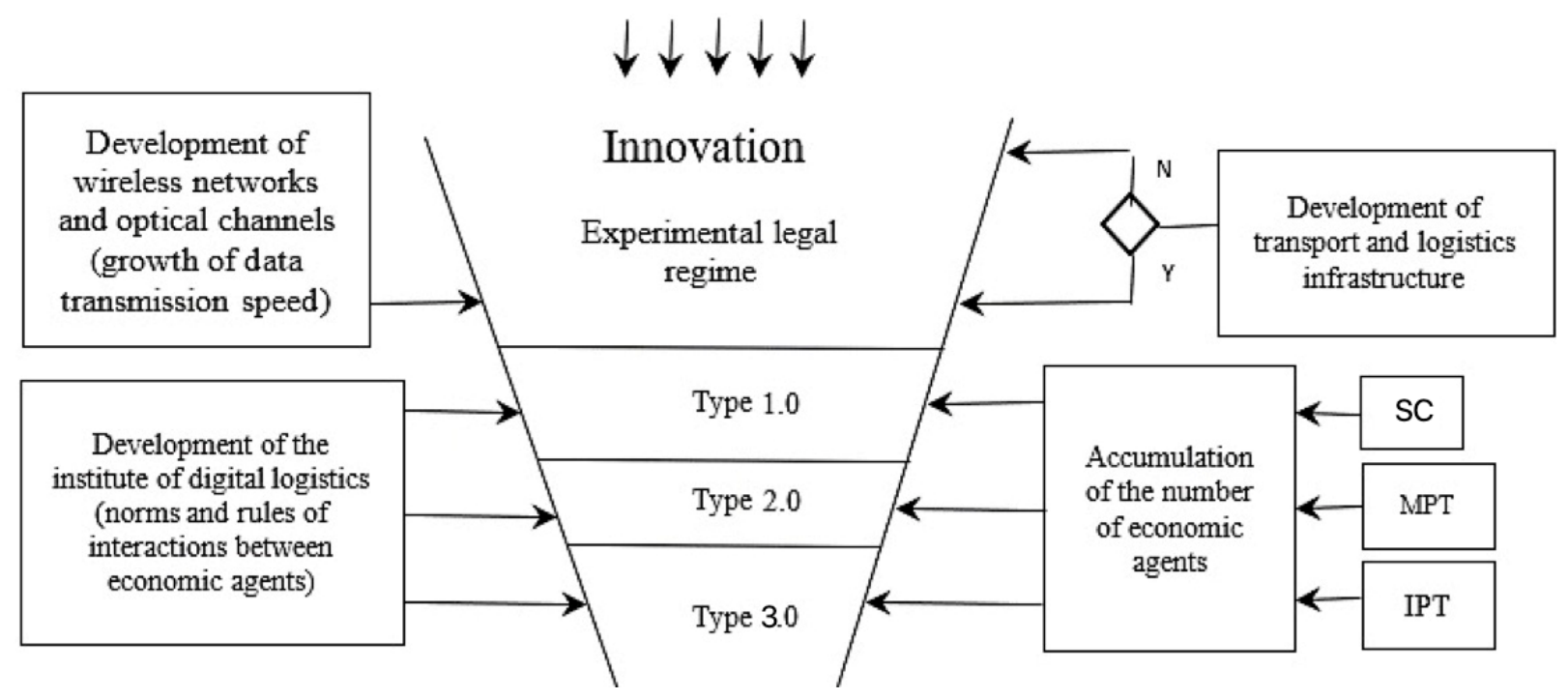

Figure 1. A mechanism for achieving the transformation criteria for the TLS of a smart city in the field of adaptive coordination.

Table 1. Directions for the development of mutations in the TLS of a smart city in the field of coordination

\begin{tabular}{|c|c|c|c|c|}
\hline No. & Gene (Mutation) & 1.0 & 2.0 & 3.0 \\
\hline G1 & $\begin{array}{l}\text { Replacement of routine operations } \\
\text { in the field of interorganizational } \\
\text { interaction between economic } \\
\text { agents }\end{array}$ & ERP, TMS, RFID & ERP II & $\begin{array}{l}\text { Cloud computing, } \\
\text { semantic networks, } \\
\text { predictive analytics }\end{array}$ \\
\hline G2 & $\begin{array}{l}\text { Reliability, accuracy and security } \\
\text { of transmitted digital information } \\
\text { in real time }\end{array}$ & EDI & $\begin{array}{l}\text { IOT, Big Data, } \\
\text { Sensor } \\
\text { technologies }\end{array}$ & $\begin{array}{l}\text { Blockchain 2.0, Smart } \\
\text { Contracts }\end{array}$ \\
\hline G3 & $\begin{array}{l}\text { Involving consumers in managing } \\
\text { streaming processes }\end{array}$ & CSRP in supply chains & CSRP households & $\begin{array}{l}\text { CSRP of all flow } \\
\text { processes }\end{array}$ \\
\hline G4 & $\begin{array}{l}\text { Intelligent Automatics well- } \\
\text { established decision-making } \\
\text { algorithms }\end{array}$ & Enterprise information system & $\begin{array}{l}\text { Corporate } \\
\text { information system }\end{array}$ & Integrated control system \\
\hline G5 & $\begin{array}{l}\text { Adaptive efficiency (control of } \\
\text { transaction costs according to the } \\
\text { established norms of interactions) }\end{array}$ & Intelligent transportation system & $\begin{array}{l}\text { In supply chains } \\
\text { (SC) }\end{array}$ & All flows \\
\hline G6 & Open architecture & Web 1.0 & Web 2.0 & Web 3.0 \\
\hline G7 & Complexity of interaction & $\begin{array}{l}\text { Participants of streaming } \\
\text { processes: mass and individual } \\
\text { passenger transport (MPT and } \\
\text { IPT) and SC }\end{array}$ & $\begin{array}{l}\text { All cyclical } \\
\text { streaming } \\
\text { processes in the } \\
\text { TLS of a smart } \\
\text { city }\end{array}$ & $\begin{array}{l}\text { All flow processes of } \\
\text { functioning and } \\
\text { development }\end{array}$ \\
\hline G8 & $\begin{array}{l}\text { The dynamic nature of } \\
\text { infrastructure development }\end{array}$ & For SC & For MPT and IPT & $\begin{array}{l}\text { Dynamic infrastructure of } \\
\text { the transport and logistics } \\
\text { system }\end{array}$ \\
\hline
\end{tabular}


processes, coordinated improvements on the basis of an appropriate evaluation system and its open architecture.

Let us highlight the mutations that need to be coherently and systematically developed and monitored in order to develop modern systems of management of city flow processes (Table 1). As a result, for each type institutions which determine the interaction between economic agents are partially formed; for a deeper integration, but to ensure adaptive coordination of flow processes new ones are needed. Their transformation has a direct structural relationship with the quantitative indicator or a set of economic agents with the growth of trust and cooperation, which is realized through the system of CSRP.
As a result, the formation of smart city TLS 3.0 provides control over organization of transportation in real time, as well as savings to the participants of the flow processes with a rational choice of mode of movement and the involvement of all consumers in the management.

The implementation of the gene transfer process is provided by the mechanism of achieving the criteria of smart city TLS transformation in the context of "regulatory sandboxes" (Figure 1).

In this situation transactional costs are influenced by accumulation and evolutionary selection of the number of economic agents with certain criteria of functioning, while there is formation of integrated genes of smart city TLS, which can be called "established majority" at a

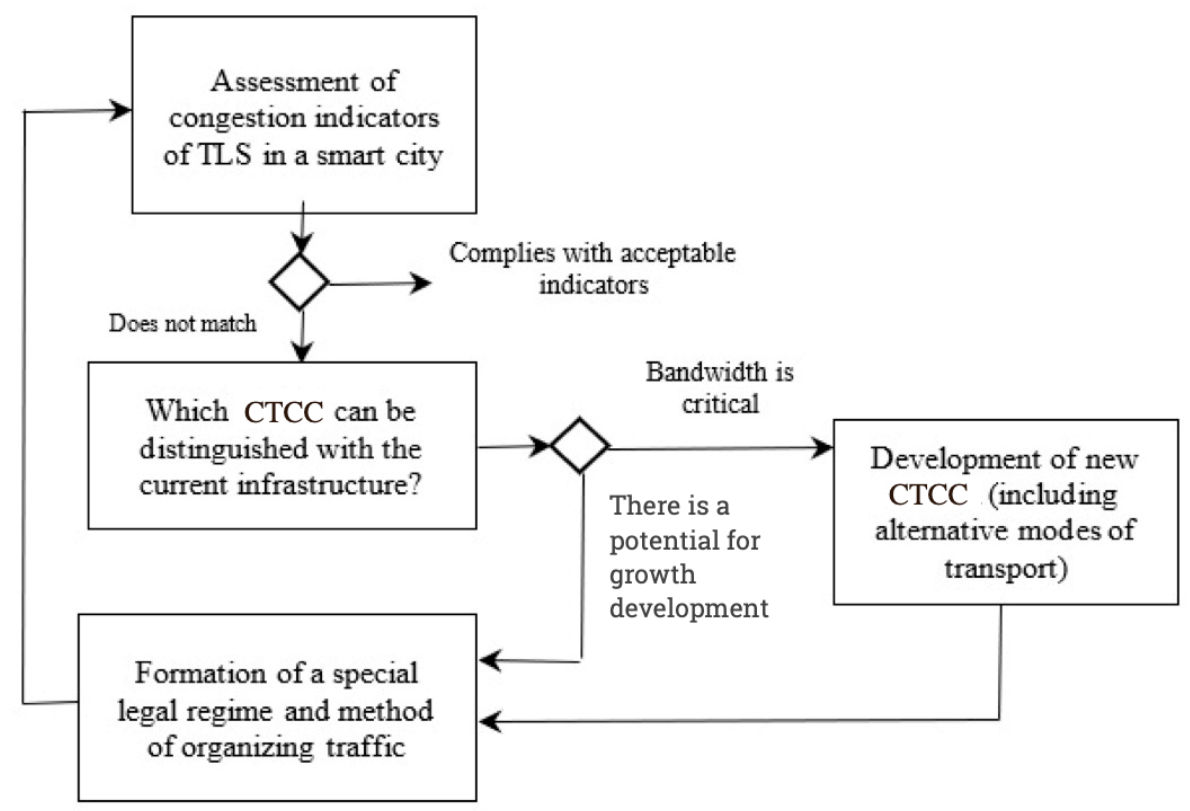

Figure 2. Mechanism for the development of urban transport and communication corridors TLS of the smart city.

Table 2. Development of the digital logistics institute in the field of adaptive coordination of streaming processes in the TLS of a smart city.

\begin{tabular}{|c|l|}
\hline Direction & \multicolumn{1}{c|}{ Explanation } \\
\hline Control & $\begin{array}{l}\text { Ensures implementation of rules and regulations for the interaction of economic agents in the } \\
\text { information space, fair distribution of risks, economic, information and cyber security; also } \\
\text { organizes functioning of the system integrator and the achievement of savings for economic agents } \\
\text { (minimization of transaction costs). }\end{array}$ \\
\hline Service support & $\begin{array}{l}\text { Provides dynamic nature of the sharing and development of infrastructure and vehicles, as well as } \\
\text { training of the necessary personnel. }\end{array}$ \\
\hline $\begin{array}{c}\text { Transformations and } \\
\text { interactions }\end{array}$ & $\begin{array}{l}\text { Forms an information space operating on the principle of Smart contracts (self-executing algorithms) } \\
\text { in the field of rational choice of a method of movement or transportation in the TLS of the smart city } \\
\text { while organizing access and dynamic pricing in real time; also stimulates innovations in the field of } \\
\text { improving coordination processes, increasing trust, cooperation and involvement of economic agents } \\
\text { in management. }\end{array}$ \\
\hline Transportation process & $\begin{array}{l}\text { intelligently manages movement process and the process of adaptive coordination of flow } \\
\text { processes; also provides a reduction in system friction in the field of movement control and } \\
\text { organization. }\end{array}$ \\
\hline $\begin{array}{c}\text { Knowledge generation } \\
\text { and implementation }\end{array}$ & $\begin{array}{l}\text { Identifies current problems in the field of organizing movement at the request of consumers in real } \\
\text { time, suggests ways to achieve them, shortens the time for approbation and implementation, taking } \\
\text { into account "regulatory sandboxes". }\end{array}$ \\
\hline
\end{tabular}


certain point in time. This statement allows to judge the achievement of critical indicators, when we can talk about the achievement of an appropriate level of coordination and reducing the level of transaction costs.

At present, the role of conflicts between economic agents in the field of transactions in transportation, which are expressed by slowing down the flow processes or complete (partial) blockage, is high. With the purpose of leveling these risks, an alternative vector of development in relation to traditional approach in development of TLS of smart city is the development of city transport and communication corridors (CTCC) as corresponding transport and logistics infrastructure, which allows forming cooperative (autonomous) transport and logistics systems as prototype of hybrid systems that combine centralization, decentralization and selforganization of flow processes. Their development will allow to form a balance of management of flow processes with the use of multi-agent systems (MAS), which allow to make decisions independently within the boundaries of their competence with different variability of models.

Introduction of certain speed modes in the organization of transportation through the CTCC will ensure the coordination of flow processes and reduce investment in new infrastructure, as this indicator depends on the mechanism of their development (Figure 2).

As a result, in the development of the share and network economy, there is a need to isolate the institution of digital logistics in the field of adaptive coordination of flow processes, which will provide control, transformation and more effective interaction between participants of flow processes in information space, as well as will organize service support, transportation process, knowledge generation and implementation (Table 2).

The author's proposed approach focuses on the development of adaptive coordination of flow processes and is based on the prediction of future arrangement and generation of technology, and on targeted investment in cooperative smart city TLS with the allocation of CTCC as its component structure and the development of the institute of digital logistics.

As a result, an ecosystem of smart city TLC is formed $[13,14]$, which controls and organizes all transportation (movement) processes through a system integrator, as well as provides a rational choice of alternatives in hybrid functioning and social interaction.

\section{CONCLUSION}

Today replacement of routine operations in the field of interorganizational interaction between economic agents is not implemented in a comprehensive way. This requires clear and reasonable actions aimed at intensification of efforts in conditions of understanding the necessary result in the field of coordination of flow processes.

Involvement of consumers in management allows to build a system including flow processes of resources attraction (crowdfunding, fundraising) under new ideas in the field of sustainable development, as well as their wishes. In this case, the more economic agents will have access to an integrated management system, the greater the pool of innovations, focused on improving the process of transportation in real time and the quality of life, will be $[2,6,7,9,12,15,16]$, life.

We emphasize that no one cancels the "invisible hand of the market", which ensures the rational selection of both innovations and economic agents in supply chains, ensuring the transfer of allocated genes into transport and logistics systems of a new type. We believe that cooperation acts as an alternative and necessary stage of interaction to achieve a competitive advantage for joint development.

The state, influential groups, as well as institutional matrix restrain changes. Anyway, evolutionary processes provide transformations and transformational costs are now included in the list of costs of business, for which introduction of innovations to gain an advantage in the framework of schumpeterian competition is critical. Optimization of flow processes cannot be solved at its expense only, at present this process requires a comprehensive alterative approach, which considers all stakeholders and ensures economizing and planned development

Complex implementation of mutations for the majority of economic agents will provide an increase in the consistency of transactions, but will not fully solve the issue of cooperation and trust, which should be determined by the institution of digital logistics, which reduces the level of transaction costs and ensures the most effective adaptive coordination of flow processes in the TLS of the smart city.

\section{REFERENCES}

[1] F. Hayek, The theory of complex phenomena. Emergence: Complexity and Organization (2007). DOI: https://doi.org/ 10.emerg/10.17357.4e008a2d2e0301f038b838fd03 db9d66.

[2] M. Gohar, M. Muzammal, A. Ur Rahman, SMART TSS: Defining transportation system behavior using big data analytics in smart cities in: Sustainable Cities and Society, 41 (2018) pp. 114-119. DOI: https://doi.org/10.1016/j.scs.2018.05.008.

[3] P. Næss, I.-L. Saglie, T. Richardson, Urban sustainability: is densification sufficient? in: European Planning Studies, 28(1) (2020) pp. 146- 
165. https://doi.org/10.1080/09654313.2019.1604633.

[4] T. Yigitcanlar, Md. Kamruzzaman, Smart Cities and mobility: does the smartness of Australian cities lead to sustainable commuting patterns? in: Journal of Urban Technology, 26(2) (2019) pp. 21-46. DOI: https://doi.org/10.1080/10630732.2018.1476794.

[5] G. Savin, Smart City Logistics in: First conference on sustainable development: industrial future of territories (2020). DOI: https://doi.org/10.1051/e3sconf/202020804005.

[6] R.A. Acheampong, F. Cugurullo, I. Dusparic, M. Gueriau, The transition to autonomous cars, the redesign of cities and the future of urban sustainability in: Urban Geography, 02 (2020) pp. 1-27. DOI: https://doi.org/ doi.org/10.1080/02723638.2020.1746096.

[7] F. Behrendt, Mobility and data: cycling the utopian Internet of Things in: Mobilities, 15 (2020) pp. 81105.

DOI: https://doi.org/10.1080/17450101.2019.1698763.

[8] A. Belbachir, A. El Fallah-Seghrouchni, A. Casals, M. Pasin, Smart mobility using multi-agent system in: Procedia Computer Science, 151 (2019) pp. 447454.

DOI: https://doi.org/10.1016/j.procs.2019.04.061.

[9] A.A. Ceder, Urban mobility and public transport: future perspectives and review in: International Journal of Urban Sciences, 29 (2020) pp. 1-25.

[10] G. Savin, Information support of the flow processes in the smart city transport and logistics system: methodology basis. International scientific forum on computer and energy Sciences in: WFCES (2021). DOI: https://doi.org/10.1051/e3sconf/ 202127001017.

[11] W. Hu, J. Dong, B.-G Hwang., R. Ren, Z. Chen, A Scientometrics Review on City Logistics Literature: Research Trends, Advanced Theory and Practice in: Sustainability, 11 (2019). DOI: https://doi.org/10.1016/j.cose.2018.06.004.

[12] S. Paiva, M.A. Ahad, G. Tripathi, N. Feroz, G. Casalino, Enabling Technologies for Urban Smart Mobility: Recent Trends, Opportunities and Challenges in: Sensors, p. 21 (2021). DOI: https://doi.org/10.3390/s2106214.

[13] A. Collado, C. Kakderi, N. Komninos, A. Panori, I. Papadaki, Digital Transformation of City Ecosystems: Platforms Shaping Engagement and Externalities across Vertical Markets in: Journal of Urban Technology, 14 (2020) pp. 1-22. DOI: https://doi.org/10.1080/10630732.2020.1805712.
[14] A. Longo, M. Zappatore, S.B. Navathe, The unified chart of mobility services: Towards a systemic approach to analyze service quality in smart mobility ecosystem in: Journal of Parallel and Distributed Computing, 127 (2019) pp. 118-133. DOI: https://doi.org/10.1016/j.jpdc.2018.12.009.

[15] C. Zheng, J. Yuan, L. Zhu, Y. Zhang, Q. Shao, From digital to sustainable: A scientometric review of smart city literature between 1990 and 2019 in: Journal of Cleaner Production, p. 258 (2020). DOI: https://doi.org/10.1016/j.jclepro.2020.120689.

[16]R. Devadas, M. Mathirajan, R. Ramanathan, Transport analytics in action: A cloud-based decision support system for efficient city bus transportation in: Journal of Information and Optimization Sciences, 05 (2020) p. 146. DOI: https://doi.org/10.1016/j.techfore.2019.119771. 